national ethnography and cultural history of Wales from the Act of Union of 1536 to the present day, with the proviso that the modern industrial civiliza. tion will not be covered, save to a limited degree. It will, therefore, concern itself with the trades and crafts, the ways of living and working, the domestic and industrial environment, and the clothes and customs of past generations of all ranks of the Welsh people. The enhanced status of this section of the National Museum is no more than due recognition of the value of a piece of work to which much time and research have been devoted by the responsible authorities, and from which important studies have already accrued. The collections at Cardiff illustrating the life and culture of the Welsh people-even more now that this opportunity for expansion is afforded them-provoke regret that no similar unitary collection deals in like manner with the folk history of England.

\section{Future of Liquid Fuel Production}

Sir Phimip Dawson's presidential address to the Institute of Fuel on October 15 entitled "Road, Rail and Fuel" emphasized our dependence on imported liquid fuel, and especially motor spirit. He stated that in the present year, Germany will produce more than fifty per cent of her needs of light motor fuel. The use of Diesel fuel is increasing in all forms of transport. Discussing the relation of road and rail, he said that the former employs almost twice as many persons as the railways, and in ten years the number of railway employees has fallen by fourteen per cent. Sir Philip advocated an extension of railway electrification, but pointed out that this would involve a big reduction in the consumption of coal, even were the power generated from steam boilers. At the same meeting Dr. Franz Fischer, of the Kaiser Wilhelm Institut, Mulheim, delivered the Melchett Lecture to the Institute, taking as his subject the conversion of coal into liquid motor fuels and other products by way of carbon monoxide. Having indicated the advantages of beginning with a single pure gas such as carbon monoxide rather than raw coal, as in direct hydrogenation, Dr. Fischer traced the development of his work from 1921 until the present stage when large-scale plant is in use. Very extensive efforts were necessary in the search for a suitable eatalyst and a method for adequately purifying the gaseous raw material. Hydrocarbons ranging from petrol to paraffin wax are obtained by this 'Kogasin' synthesis. Thus these researches have shown that from coal and water all necessary liquid fuels would be obtainable from coal even if mineral oils were entirely exhausted. Fischer's process offers the advantage over the process of direct hydrogenation, that high pressures are not used and that only plant of common materials, easy to fabricate, is required.

\section{Electric Services in Buildings}

Mr. H. T. Young, who is connected with the installation and contracting section of the electrical industry, gave his presidential address before the Institution of Electrical Engineers on October 22.
In the early days, electrical installations in buildings were for lighting and bells. Wood casing was used, and, so far as possible, it was concealed from view. Cables, wires and equipment were placed anywhere where they would be out of sight. Now new and larger buildings are being erected all over the country, and electrical contractors are having difficulty in doing their work satisfactorily under the new conditions. The steel and concrete buildings of to-day, if once completed, are almost impregnable to electric services. The item in electrical accounts entitled "cutting away and making good" averages about ten per cent of the cost of the whole installation. In new buildings which are planned and designed for electrical services, this item is much smaller and the time of building is accelerated; Mr. Young urged that channels, ducts and conduits for the reception of wires and cables should be considered in the future as an integral part of the building from the point of intake to the outlets. In the United States and Canada, underfloor duct systems have been adopted for more than ten years as standard practice in nearly every type of building, except private houses. The ducts are made of steel or fibre and are laid in the floor during construction. In Great Britain, a beginning of the duct systern has been made. Three ducts are used, one for telephones and signalling wires, one for heating and power, and one for lighting.

Mr. Yound showed lantern slides of installations in progress and completed where electrical engineers and architects have planned their work together. In particular, he mentioned the new buildings of the University of London, which he said are the most interesting buildings in the course of erection in the country to-day, and also seem to have the most complete electrical installation, as the lighting, spaceheating, water-heating, and many other services ar' all electric. There is one flue only, and that is for a coal fire in an official's study. In blocks of flats in London, arrangements are now being made for the reception of sound and television services. These are taken from one central aerial system and distributed by cables to a terminal box in each flat. The tenant receives both services on his own equipment through a 'soeket outlet' and plug attachment. A special type of cable is used for carrying the extremely high frequency currents used in television. The estimated total annual consumption of all-mains radio sets is 300 million units. This equals twice the estimated load in 1910 for lighting, heating and cooking. He mentioned that a large store in London (Selfridge's) has an annual consumption of electricity ( $7 \frac{1}{4}$ million units) which equals that of places like Weymouth, Perth, or the whole of the Isle of Wight. There are other buildings in London, such as stores and hotels, which consume five million units per annum. $\mathrm{He}$ considers that none of these could be described as fully equipped electrically.

\section{The Training of the Engineer}

IN his inaugural address as president of the North-East Coast Institution of Engineers and 